\title{
SOCIAL MATRIX AND CONSTRUCTION OF GENDER IDENTITY IN NATHANIEL HAWTHORN'S THE SCARLET LETTER
}

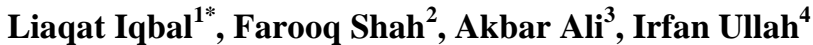 \\ ${ }^{1 *, 4}$ Assistant Professor, Department of English, Abdul Wali Khan University, Mardan, Pakistan; ${ }^{2}$ Lecturer, Department of \\ English, Abdul Wali Khan University, Mardan, Pakistan; ${ }^{3}$ Assistant Professor, Department of English, FATA \\ University, Pakistan. \\ Email: ${ }^{1 *}$ liaqat@awkum.edu.pk, ${ }^{2}$ farooq@awkum.edu.pk, ${ }^{3}$ akbar@fu.edu.pk, ${ }^{4}$ irfanullah@awkum.edu.pk \\ Article History: Received on $31^{\text {st }}$ March 2021, Revised on $19^{\text {th }}$ April 2021, Published on $6^{\text {th }}$ May 2021
}

\begin{abstract}
Purpose of the study: The Scarlet Letter by Nathaniel Hawthorn, already explored from different perspectives by many researchers, has relevance to the social matrix that how gender identity is constructed in the text. In order to explore this perspective, the study deals with the character of Hester Prynne as how she is deconstructing normative gender.

Methodology: For this purpose, the theory of 'Imitation and Gender Insubordination' presented by Butler (1993) has been applied. Secondly, the study tries to answer the gender identity of Hester Prynne by using Freudian 'Identification of gender.' Lastly, the work is concerned with Hester Prynne's avoiding the danger of being leper and castaway. The last analysis owes itself to the Freudian understanding of psychoanalysis.

Main Findings: The findings show that gender is purely volatile and oscillating and is usually being constructed by feminist narratives, social appropriations, inborn congenital schema, and sexual orientations. Butler's arguments get augmented in this study through the analysis of a few characters, particularly Hester Prynne's, and it has indicated that through the application of Butler's arguments on gender stance that gender is performative and hence, it has no real or inborn value/definitions. Therefore, it is inferred that gender is performative and is socially constructed.
\end{abstract}

Application of this study: This study has implications in literature in general, gender studies, and related fields in particular.

Novelty/Originality of this study: Though Nathaniel Hawthorn's The Scarlet Letter had been written long before that has been explored from different perspectives, the present research is original and new in the sense that it brings social matrix and discusses gender issues in it both from the social and psychological interpretations.

Keywords: Social Matrix, Gender, Identity, The Scarlet Letter, Imitation and Gender Insubordination.

\section{INTRODUCTION}

The Modern age and literary theories are siblings. They exist dependently and none is independent. The modern age has explored numerous areas that remained shrouded in mystery until the $19^{\text {th }}$ century. Before the present hullabaloo of literary criticism, texts remained in a rather undisturbed haze, in the sense that few literary theories were there to uncover a wealth of unexplored ideas and underlying themes. Starting from the very basic gender theories to the most philosophical theories on anthropology, literary criticism attracted the attention of modern readers by the late twentieth century. Therefore, literature and literary theories go side by side to uplift the standard of living and offer a better understanding of humanity. Literary theories and literature collectively try to emulate scientific achievements and to provide mankind with intellectual stimulation along with aesthetic pleasure.

Although modern literary theories have facilitated us in approaching literary texts, these theories have confused readers and even writers to some extent. The advent of a cluster of theories in the 1960s has divided critics and their entourage into different camps. Even the human physique in terms of its gender orientation has led to varying controversial opinions by the critics. Gender studies are one of those complicated studies which call for deep thinking and scholarship. Butler (2006), a philosopher and feminist writer of this Modern age, has stunned the intellectual circles of today by presenting a radically different approach towards gender studies. Particularly, her famous work Gender Trouble, has led to heated debate over gender identity and its difference from sex. Particularly, Butler's 'lesbian works' and advocacies for homosexuals have been contentiously studied in recent times and are still being considered polemical.

Butler (2006, p. 1), at the very beginning of her Gender Trouble: Feminism and the Subversion of Identity, launches her polemic. She quotes Simon de Beauvoir when she professes, 'One is not born a woman, but one rather becomes a woman'. Beauvoir's definition of gender identity on the same page is followed by Julia Kristeva's: 'strictly speaking, "women"' cannot be said to exist. LuceIrigaray conflates both male and female genders by saying, 'Woman does not have a sex'.

Looking at all these definitions or rather sweeping statements, one is compelled to think too much about how to identify oneself as a gender among all these variant definitions. As all the definitions nearly undermine the status of biological assumptions of sexed bodies, there arises a pertinent question as to how to seek a desirable definition. This complexity has made a modern reader concerned more about his/her own real gender. Judith Butler, however, resolves this confusion rather paradoxically, by explaining gender and then complicating it further. Though her remarks about the construction 
of gender as a neutrally constructed (neither male nor female) gender raise another string of questions, they are illuminating nevertheless. Butler (2006, p. 6) sees no ideal difference between both opposite genders (male and female) and hence adduces them as one gender:

When the constructed status of the gender is theorized as radically independent of sex, gender itself becomes a free-floating artifice, with the consequence that man and masculine might just as easily signify a female body as a male one, and woman and feminine a male body as easily as a female one (Emphasis in original).

These lines further intricate the fixation and exactness of the gender. If the sex is to be excluded, the gender would get automatically absolved of any bond of the categorization. How to construct gender, then?

In the book, Gender: The Sociological Reader, Jackson and Scott (2011, p. 1) define gender as 'the hierarchal division between women and men [that is diffused] in social institutions and social practices'. But on the next page of the same book, Jackson and Scott explain, 'the meaning of gender: masculinity and femininity' changes 'within as well as between, societies' (Jackson and Scott, 2011, p. 2). The restriction of gender difference to the socially accepted norms or 'social construction' of gender induced Butler to turn critical to this argument, which subsequently resulted in Butler's argument for 'Gender Performativity' as the basis for gender identity. Butler is concerned with gender identification in terms of doing gender.

Sigmund Freud's approach to gender identification is somewhat different, as Butler mentions in her book Gender Trouble, about Freud's 'object cathexis' and 'the object lost' or 'lost love' shapes the identification of gender. 'Superego' and 'ego' direct and tame the wilderness of id and gratify its melancholia of the object lost through some compensatory identity. So, melancholia diminishes while the 'id' finds solace in identifying itself with the object lost. Butler also abolishes the set categories of gender identity and attempts to find out a new way to describe gender identity in terms of 'gender performativity'. Such as through 'reiteration' of some 'conventional practices'. Butler (1993, p. 307) further claims, any attempt to reproduce an ideal heterosexual attempt will be in vain and the attainment of 'ideal heterosexuality' will not be accomplished. She mixes lesbians and gays with any gender. So, gender becomes invariably unsexed. This essay deals mainly with the 'Third Wave Movement' of feminism; the main subject of which (movement) was its question over the prevailing traditional definition of sex and gender (Bhasker, 2007).

\section{RESEARCH QUESTIONS}

1. Can aspects of performative biological sexde-materialize gender appropriations?

2. Are pure acts performed by sexed bodies enough to dismantle stereotyped gendered narratives?

\section{LITERATURE REVIEW}

Works have been done from many angle on The Scarlet Letter because of its seminal nature of producing a plethora of meanings; it's very much like a Mona-Lisa, casting forth meanings after meanings by studying and explicating it from various perspectives. Here is a list of a few works done in terms of gender appropriations and psychoanalysis.

Stineback (1985) in his work brought a radical notion of gender by complicating it in The Scarlett Letter, saying the gender is a free mass afloat the sea. The sea is actually the writers' ink where they soak their pens in it and draw the caricature of their own women's and men's idealism. The author further stands on his words by saying that, yes, Nathaniel Hawthorne, in The Scarlet Letter, does produce and offer a consolidated position to feminist narrative and the female character: Hester Prynne. Thus, creating a potential space for women to subvert gender and outwit the schematic policies of narrow-minded puritan as well as historical male counterparts of women who annihilate women's rightful position or due.

Last (1997) has put a tremendous value in the work 'Hawthorne's Feminine Voices: Reading The Scarlet Letter a Woman (1997) by presenting the novel to be feminine. The research applies that women narrative have basically come up from the notion that gender can't be undone, or perhaps females can't be excluded. And that multiple voices predominate women's or feminine's voices. The paper in the journal explains that gender, perhaps, may not or cannot be substantially shaped but the author always feels the guilt of excluding it (the gender or the female sex). Therefore, out of this guilt, or reality or sex/gender inevitability, it rushes into the author's mind to be instinctively more sympathetic to the women's voices irrespective of any gender detachment or attachment. Proving that The Scarlet Letter provides a fertile ground for a de-gendered play.

Johansson (2015) in her thesis contends that gender role is hijacked by Hester Prynne in The Scarlet Letter by doing away with the expectations or rather the standards set by the normative gender society (the puritan society in the novel). Her work compares both male and female characters in The Scarlet Letter as well as My Ántonia that is titled 'Spinless Men and Irrepressible Women'. This work tries to find out the correlation between the defined stereotypical gender roles set for a woman and the defiant woman who tries to blow them into the air.

Mise (2015) in his research points out the reluctance of the Americans to change their collective identity, though it was put to change. And in the following reference from the thesis, it is evident that collective memory of culture gender, and religion can't be excluded and hence can't be saved from impending change. Therefore, the outright policing of gender is 
put to change, though the American preservation of gender and culture both were experiencing the jolts of regeneration and degeneration.

Siebert (2017) brings forth the gender issues in the Puritan Society during the setting of The Scarlet Letter by presenting her paper Historically Motivated Gender Ambiguity in Nathaniel Hawthorne's The Scarlet Letter. The author here does not mention that gender definition or appropriation changed because of the roles it (the sex) played but because the industrialization at that time was forcing men to step out of the house and to compete with other men to find a work placement and to earn a livelihood. However, doing so, opened up spaces for women to expand their gender roles, and hence it potentially put the stereotypical gender circumscription. Bettina's work is significant but historical and expands beyond The Scarlet letter. However, the paper does not describe Prynne's role under financial obligations, thus leaving the space for the present study to explore gender roles in The Scarlet Letter under different issues.

Wang (2017) in the work, Misogyny or Feminism? A Probe into Hawthorne and His The Scarlet Letter(2017) distinctly argues that the fundamental aspect of Hawthoren's The Scarlet Letter outweighs other critics who might be of the opinion that Hester has been a female character in the novel. This is, says Wang, the only way through which Nathaniel Hawothrone undercuts the insolent anti-feminist or gender-divisive school of critics who attach to biological sex the notion of the female gender, thus proving it wrong or refuting it. Wang's research is under the impression of Hawthorne being considered a gender with voicing for the female sex. However, it is actually the gender nor sex in Hawthorne which performs the duty of gender foreplay in the novel and it is not Hester but the agony of the writer.

Vani (2017) is having a say on the aspects of Gender Conflicts in Nathaniel Hawthorne's The Scarlet Letter by presenting a detailed analysis of the mind-blowing acts of Hester Prynne were tormenting the male-dominated puritan society. The paper discussing the gender reversal of roles in the novel is by no means less valuable but it is outsmarted by the mere description of Hester Prynne's performative acts. The paper gives a detailed description of how Nathaniel Hawthorne bravely imparts energy into his fictional protagonist and that is female sex, thus puncturing the slim and haggard pride of menfolk advocating only worth in men.

Eva (2020) has taken good stead in taking up the issues of gender polemic in The Scarlet Letter. She has explored the connection of ancestry of European women living in American society with that of the strong patriarchal puritan hands and concluded that women even in modern advanced America still share the amount of subjugation as they shared in the 17th-century Puritan society presented in The Scarlet Letter. The author has audaciously pointed that Hester Prynne, a woman, has been unduly ghettoized and hence the play for gender has been given a chance to demonstrate. Though the researcher, here, does not attribute the cause to any gender issue but the narrow-mindedness of the American Puritan Society.

All the above researches from 1982 to the late 20th century have chiefly focused on Hester Prynne as a female gender or perhaps sex. The researches are fine enough to have a good analysis of Hester Prynne's character and performance but it lacks the identity of gender. This paper applies the theory of gender presented by Judith Bulter to enforce the definition of gender and filter the raw, unripe, and mal-definitions henceforth adjusted for the gender. Therefore, the gap for gender orientations is still open. This study tries to first open up the gender issue in The Scarlet Letter by eliminating any definition attached to the gender by the insolent stereotypical male-school and then attaching to it an anonymous gender whose orientations are not linked to any instinctive biological sex but undefined/unstaged performance and acts. Thus, the paper finally stages and concluding itself that gender is performative and is based on acts rather than any social or biological definition.

The researches on gender issues on The Scarlet Letter are also barren in terms of discussing it from the psychoanalytical perspectives. Therefore, the paper also discusses and hence proving gender to be volatile from Freud's point of view.

\section{METHODOLOGY}

The present research has been done with a qualitative approach and explores the character of Hester Prynne as an 'insubordinate gender' (deconstructing normative gender) in Nathaniel Hawthorn's novel The Scarlet Letter by applying the theory of 'Imitation and Gender Insubordination' presented by Judith Butler (1993). The second part of the essay further explores the character of Hester Prynne under Freudian 'Identification of gender'. Freud in 'The Ego and the Id', defines the function of 'the Ego' which is the defense of the whole structure against the disruptive effects of the lost object or the 'person that one has loved' and lost or the 'love' that is diminished (Freud, 1923). The same 'lost love' then forces the gender to re-establish itself through different gender performances mentioned by Butler under gender performativity. The last part of the essay is still concerned with the character of Hester Prynne who scrupulously avoids the danger of 'castration anxiety' presented by Sarnoff-I and Corwin. The anxiety is not in the sense of Freud's 'Phallus Circumcision' but in an implied (metaphorical) sense of losing a place within the society (Sarnoff \& Corwin, 1951).

In order to analyze the text from the perspective of gender role, first of all, the text was coded for the relevant examples and roles according to theories used. Afterward, the examples were looked for as to how the different characters are dealt with and how they represent different gender roles, and how different gender performances are mentioned. 


\section{RESULT AND DISCUSSION}

Starting with the first section of the essay, considering the attitude and 'gender performativity' of Hester Prynne, the essay moves on to 'gender insubordination' by Hester Prynne. We see that Hester Prynne appears as a protagonist of the modern age as she opposes the straitjacket of gender and goes beyond the 'gender roles' defined by WHO for 'men and women' as 'socially accepted behaviour, attributes, and activities', in a 'given society' (World Health Organization, 2015). This definition, however, delimits the definition of gender or in other words the roles performed by gender in a given society or culture. Butler is critical to defining any specificity to the classification of gender. She believes gender and sex are acted and repeated, that is, they change through performativity.

Before exploring Hester Prynne's character, let us look at the summary of The Scarlet Letter. The novel is about the seventh-century puritan society and its harsh uncompromised attitude towards women's transgressions. Hester Prynne, a woman, is accused of adultery; and an illegitimate child (Pearl) is now with her. The name of her real husband is Roger Chillingworth, who is supposed to have deserted her. The puritan society discovers her sin and asks her to wear The Scarlet Letter (A); signifying Adulterer, or possibly Adultery on her breast. Arthur Dimmesdale, the minister, is the other partner in this extramarital relationship, but he is unknown to society as the guilty person. Only Hester knows about his reality and immoral stance. Crowley describes Dimmesdale's persona in such words, (Dimmesdale) tries to hide his guilt and lives without confessing it, but suffers internally from the guilt he committed. He lacks that 'manliness to avow his share in the guilt' (Cowley, 1971). On the contrary, Hester Prynne, having the illegitimate child, the evidence of her guilt, is committed to living with the child and the scarlet letter. At last, as the confession is unavoidable to ease the burden of humiliation, Dimmesdale proclaims on the scaffold that he is the unacknowledged/unlawful father of the child (Pearl) and passes away.

By applying the notion of gender performativity to the character of Hester in The Scarlet Letter, this essay analyses her character from the perspective of gender identity. Noomi Sandstorm writes in a thesis, 'Open Guilt and Secret Shame' in The Scarlet Letter, regarding the dexterity of Arthur Dimmesdale to conceal the guilt he experiences inwardly, the guilt according to Sandstorm is the opportunity which is presented to him by the non-appearance of outward signs of the guilt. About Hester, Sandstorm says, 'she is depicted as strong, self-reliant, and free-thinking.' but Sandstorm believes, these manly traits of Hester are unacceptable to the narrow-minded Puritans (Sandstorm, 2004, p. 15). Following, Sandstorm's ideas about Hester's personality, it can be said firmly that the puritans in Hester's society cannot tolerate a woman as strong and independent as the one Sandstorm depicts. In other words, we can say that Hester is supposed to yield to the social pressure, the pressure exerted by the puritan society to harness and tame Hester. A similar situation gives birth to the idea that Hester shows a masculine gender. She is deconstructing feminine gender and constructing masculine gender within herself. As Butler preaches the idea of constructing gender through gender performativity, her idea is true for Hester. The behaviour, personality, and actions of Hester construct her gender as masculine, irrespective of her biological sex.

Donald. L, Nathanson notes a point about Hester in a way that shows her as a man. Although Hester experiences imprisonment and takes the rebuke of the women in front of the prison door, yet she never remains subjugated to the 'thoughts of society' (Nathanso, 1992). What we can assume from Nathanson's remarks, is Hester's perseverance and unyielding attitude that make her as stalwart as a man. She shows an uncompromised attitude to accept her feminine gender, which in turn leads her to 'drag' Butler's (2006, p. 157). The idea that men and women wear each other dresses and hence show deviant genders. However, there is no transvestitism, yet the way she behaves and grows under the atrocity and snobbishness of the puritan society stands perfectly bold, shows no effeminate attributes, are the solid evidence of a male-natured gender if the societal criterion is to be accepted.

Beker in the book, Hawthorn's Historical Allegory comments about Hawthorn's characterization of Hester Prynne as she has taken such a symbol which was to make [Hester] another allegorical figure in the Puritan allegorical world and by the force violent [skill] has turned into an expression of her own defiant individuality (Becker, 1971).

Becker shows his concern allegorically about Hester's art to transform her womanhood into manhood. We can say that 'skill' with Hester is the skill of gender transformation. Here are some lines from the novel that suggest her character as masculine. She seems to be acting in a way as if she were the beadle in the novel. At the opening of the novel, among so many ill-wishers, Hester makes her way fearlessly to the scaffold to face opprobrium. As she comes out of the prison, a sea of people is eager to witness the drama, her action is described as:

She repelled him [the pastor], by an action marked with natural dignity and force of character, and stepped into the open air, as by her own free will. (Hawthorne, 1850, p. 49)

Even the women stationed right at the front of the prison door calling her 'hussy', and 'naughty baggage,' (Hawthorne, 1850 , p. 48). Things get worse for Hester Prynne when even the women (of her real gender) were against her. In the following pages of The Scarlet Letter, the narrator's description of Hester tells that she carries herself with a markedly 'haughty demeanour ( Hawthorne, 1850, p. 52). More than her superciliousness and egoism, it shows the strength of her character. This style of Hester is the hint of masculinity in her character. Naturally, Hester, being a woman, we expect from her, utter submissiveness, humbleness, and a slightly sheepish attitude. But she does not show any signs of these. 
That is why Hester strips off her female (gender) identity and wears on male (gender) identity to face boldly the situation of being publicly disgraced. She is 'undoing' her gender. In an implied way, she proves Butler's theory of gender insubordination. Hester's insubordination to the social norms and implementations is consistent throughout the novel. When she returns to the prison, it is the likelihood that she would be humbled by the incident that occurred on the scaffold, but she is adamant as Nathaniel Hawthorn makes it clear at the beginning of chapter four in The Scarlet Letter.

As night approached, it [became increasingly] impossible to quell her insubordination by rebuke or threats of punishment. (Hawthorne, 1850, p. 54)

Hester's resilience once again proves itself insurmountable by continuing to live among the unwelcoming puritans and facing their deadly darting arrows of curses that pierced her all over. And, precisely this adds a masculine tinge to her character. She seems not the one to be bothered by the derisive remarks of the puritan society. Nathaniel Hawthorn presents her in The Scarlet Letter as the undismayed woman with unshakeable faith.

Here, she [Hester] said to herself, had been the scene of her guilt, and here should be the scene of her earthly punishment,... Hester Prynne, therefore, did not flee. (Hawthorne, 1850, p. 72)

After depicting her boldness and her consistent inflexibility, Hawthorn juxtaposes her with the character of Roger Chillingworth, her real husband, who betrays unmistakable signs of flinching against the odds. He informs Hester that the magistrates might budge on the issue of her wearing the scarlet badge (A), but Hester's refusal to doff the letter A, betokens her commitment, bravery, and manliness.

[Chillingworth], Yonder scarlet letter might be taken off your bosom...[Hester] It lies not in the pleasure of the magistrates to take off this badge,... Were I worthy to be quit of it, it would fall away of its own nature. (Hawthorne, 1850, p. 150)

Hester living alone with a small child in a distant cottage is not womanliness but manliness. She performs utter masculinity. All these pieces of evidence corroborate the idea that Hester deconstructs her own gender and transvestite herself to a masculine gender. The social forces do not deteriorate her personality but rather beef it up, and engender her new gender.

T. Walter Herbert, argues, Nathaniel Hawthorn himself was critical of any specific definition attached to manhood. Or he was primarily displeased with the cultural specifications of gender. Walter further quotes, 'Nathaniel Hawthorn felt his characters were anomalous to the standard of master public manhood' (Herbert, 1988, p. 285). We can justly assume that Hawthorn in a sense consciously represented his characters as anomalous to support feminism and the dismissal of gender discrimination. Therefore, he deliberately attributed the suppositional manliness to Hester Prynne. Walter is right in saying that Nathaniel Hawthorn felt his characters fail to follow the standard norms (Herbert, 1988). It may be said, Hawthorn knowingly did so to create a stable ground for the women of the Victorian society, and to stop the unduly oppressive attitude of the puritans towards the Victorian women. Barbara Ellis in an article proves the point made above about Hawthorn's stance regarding the women of Victorian society. 'Hawthorn', says Ellis, never viewed women as insignificant or 'threatening Eves' but rather 'men's emotional, intellectual, and spiritual companions' (Barbara, 1993, p. 13). So, Hawthorn represented Hester as the anomalous (masculine) character to raise voice for women's rights.

Hester is the one who subordinates social forces, though it is not expected from her to keep the gender norms in consideration. She also deconstructs her biologically sexed-gender. Butler in Gender Trouble is concerned with the same notion that gender cannot be stable and should be assumed under the title of the performance. As mentioned earlier in the essay, gender categories are merged or abolished by Butler. Had it been the case that gender roles are performed universally, we, then, would have seen Hester's submissiveness and docility in The scarlet letter.

This section of the essay is concerned with the identification of gender under Freud's idea of the Oedipal Complex. This section explores the idea that how Hester identifies herself or constructs her gender after losing her husband Roger Chillingworth. The idea that a girl identifies herself either with her mother or with her father, recognizing her sex as well as gender in the 'phallic' stage of her infantile life, is put forward by Freud, an eminent psychologist, and is later modified by Benjamin in The Unconscious Mind (1968). This essay applies the later version of the theory presented by Benjamin in his book The Unconscious Mind.

Some critics have analysed Dimmesdale's character and Chillingworth's under the psychoanalysis of Freud's Oedipal Complex. Murfin mentions in his work 'Contemporary Criticism' in The Scarlet Letter, Dimmesdale has a strong sexual desire towards Hester. But Hester is forbidden as an object of desire to Dimmesdale. Murfin believes Dimmesdale impersonates Hawthorn because Hawthorn lost his mother soon in his early life. He uses words like 'scourging and writing' for it to compensate for that repressed desire (Murfin, 1962, p. 231). It means this is Hawthorn, the author, who resolves his oedipal dilemma in The Scarlet Letter. 'Literature and Psychology', an article by Lefcowitz, suggests, 'Chillingworth is not the father of Pearl, but Dimmesdale is the father of the Pearl. Lefcowitz further says that Chillingworth represents the 'oedipal son' when he becomes jealous of Dimmesdale who lives near his wife (Lefcowitz, 1974). Lefcowitz carefully charts the tangle of the oedipal dilemma. Murfin stresses the point that Dimmesdale is the 'oedipal son' and Lefcowitz insists on Chillingworth whom he thinks to be the actual oedipal son. Both think oppositely. 
However, this essay discusses Hester as the 'oedipal women'. A term that is used unnaturally to the concept of 'oedipal son' but as a 'gender' Hester has not been explored under Oedipal Complex so far.

As mentioned earlier, Benjamin in his book The Unconscious Mind talks about the initial stages of infantile development under Freud's Theory of Psychoanalysis. His concept restricts the study to the identification of biological gender and sexuality. This essay extends Benjamin's theoretical framework to analyse the character of Hester to know the genuineness of her gender; not to explore her sex whether she is female or male but to know the gender she performs in the aftermath of losing her husband, Chillingworth. Benjamin writes in his book 'The Unconscious Mind', the boy stays unchanged in the selection of his object for love, that is mother usually, whereas girl shifts her course in the selection of an object for love after repressing her desire, either towards father from the mother or vice versa (Wolman, 1968). We can apply this statement to Hester, who changes her course from Chillingworth (lost object or love) to Dimmesdale (object for the consolation of id). She stays heterosexual to be still attracted to the opposite sex. And this mark of sensuality is an expression of the repressed desire for sexual intercourse lurking in Hester's id.

This is clear in The Scarlet Letter that Hester falls a victim to the lustful act with Dimmesdale. But Dimmesdale cannot be held solely responsible for the seduction. Though the novel is silent about it, we can assume that Hester might have played coquetry to arouse his interest to do so. But when Dimmesdale and Hester both stay away from her (object prohibited or denied), then Hester internalizes in her id the same lost object or lost love or more truly she impersonates the male gender (Dimmesdale or Chillingworth). That is why Hester then finds maleness within herself. Freud's opinion regarding the id that id assumes that object or internalizes it in a refined and acceptable manner. Another thing that can be said about Hester is her needlework and this profession gratifies her repressed sexual desires. This provides the grounds for this essay to call Hester a masculine gender. Hester's maleness embodies an oxymoron regarding her gender, she is a 'masculine women'. She imitates (Butler's 'Imitation and Gender Insubordination') masculine gender to compensate the 'lost object' and displace the male gender.

The last part is concerned with Hester's social position; how does Hester keep her identity within the regime of social forces. She knows how to thwart the social forces and not to duck under them. She is worried to be a leper afterward. Therefore, this masculine act is a safety guideline a well. Corwin's idea of 'castration anxiety' is Hester's endangered position in puritan society. She never surrenders and keeps in mind if she yielded to any overarching intimidation, she would be not less than a leper. The social forces have a positive impact on her inner self and she becomes a gender that holds the principle of antinomianism. She trespasses the social forces and stays rebellious to the very end. Murfin (1962, p. 231) approximates Hester's role in chapter thirteen of The Scarlet Letter, he says:

Hester goes so far [to make] the whole social system anew [modifying] sex roles so completely that both womanhood and manhood will become unrecognizable to themselves.

Murfin thinks rightly about Hester's character that she blurs the distinction between the genders. His argument has the capacity to underpin Butler's statement of' 'Gender Instability' under different performances. The forest scene in The Scarlet Letter, in which she tosses up the scarlet letter (A) and unravels her hair, is a proven episode of how she breaks off with the social forces and toys with moral duties.

\section{CONCLUSION}

This research has looked into various aspects of gender identity and sexed identity. There is no denial of the biological sex but the role and connotative meanings we have associated are worth considering. It does not depend on gendered and sex strength; rather it is individual strength that is responsible. We conclude that gender roles are not defined. They can trespass these roles.

\section{LIMITATION AND STUDY FORWARD}

We prove that gender is volatile and at the same time floating. However, there are hard and antifeminist authors who do not accept this phenomenon. They see historical weakness in women. The limitation of this research is that hypothetically and through social research, we limit their presence but in reality, we cannot disregard them. Although we researched gender role in the present text, it is recommended for future researches that gender should be researched parallel with the historical narratives and it should be looked at that what voices are strong.

\section{ACKNOWLEDGEMENT}

The paper was sent to our friends for feedback. We are thankful to them for their valuable suggestions and feedback.

\section{AUTHORS CONTRIBUTION}

Farooq Shah wrote the research essay. Dr.Liaqat Iqbal added different headings and relevant matters according to the format of the journal and set references accordingly. Dr. Akbar Ali and Irfan Ullah worked on method specifications.

\section{REFERENCES}

1. Barbara, E. (1993). Some observations about Hawthorne's women. WILLA, II, 13-18. 
2. Becker, J. E. (1971). The scarlet letter. Hawthorn's Historical Allegory. London: National University Publication.

3. Bhasker, S. (2007). Feminist movement-An introduction. In Shukla Bhasker (ed.) American Feminism: A Critical Study, pp.7-8. Jaipur: Book Enclave.

4. Butler, J. (1993). Imitation and gender insubordination. In Henry Abelove et al (eds.). The Lesbian and Gay: Studies Reader, pp. 307-320. London: Routledge.

5. Butler, J. (2006) Gender trouble: Feminisms and subversion of identity. London: Routledge.

6. Cowley, D. J. ed. (1971). Hawthorn: The critical heritage. New York: Barnes.

7. Eva, G. S. (2020). Feminist and mainstream comparative analysis in The Scarlet Letter.\| Journal of Artistic Creation and Literary Research, 8(1). Retrieved from https://www.ucm.es/siim/file/jaclr-815garrido

8. Freud, S. (1923). The ego and the super-ego'. In James Strachey (ed.) The Ego and the Id. New York: Norton.

9. Herbert, T. W. (1988). Nathaniel Hawthorn, Una Hawthorn, and the scarlet letter', Interactive Selfhood and the Cultural Construction of Gender Identity. 103 (103), 285-297). https://doi.org/10.2307/462377

10. Hawthorne, N. (1850). The Scarlet Letter. Boston, MA: Ticknor and Fields.

11. Jackson. J. \& Scott, S. (2011). Gender: A sociological reader. London: Routledge.

12. Johanssan, S. (2015). Spinless Men and Irreprsible Women: Gender Norm Destabilizing Performances in The Scarlet Letter and My Ántonia: UMEA Universitet. Rsetrieved from https://www.diva-portal.org/smash/ge t/diva2:819333/FULLTEXT01.pdf

13. Last, S. (1997). Hawthorne's Feminine Voices: Reading "The Scarlet Letter" as a Woman. The Journal of Narrative Technique, 27(3), 349-376. Retrieved from http://www.jstor.org/stable/30225475

14. Lefcowitz, A. (1974). Apologia, Pro Roger Prynne: A psychological study. Literature and Psychology, 24, 3443.

15. Mise, C. (2015). "Counter-monumentalism in the Search for American Identity in Hawthorne's The Scarlet Letter \& The Marble Faun" (2015). FIU Electronic Theses and Dissertations. 2186. https://digitalcommons.fiu.edu/etd/2186

16. Murfin, R. C. (1962). The scarlet letter: Case studies in contemporary criticism. Boston: Ohio State University Press.

17. Nathanson, D. L. (1992). Shame and pride: Affect, sex and the birth of the self. New York: Norton and Company.

18. Sandstorm, N. (2004). Open Guilt and Secret Sham'D Extended Essay. Lulea University of Technology.

19. Sarnoff-I, \& Corwin, S.M, (1951).Castration anxiety and fear of death, Journal of Personality, 27(3), 374-385. https://doi.org/10.1111/j.1467-6494.1959.tb02360.x

20. Siebert, B. (2017). Historically motivated gender ambiguity in Nathaniel Hawthorne's "The Scarlet Letter", Munich, GRIN Verlag, Retrieved from https://www.grin.com/document/459922

21. Stineback, D. (1985). Gender, Hawthorne, and Literary Criticism. Mosaic: A Journal for the Interdisciplinary Study of Literature, 18(2), 91-100. Retrieved from http://www.jstor.org/stable/24777585

22. Vani, M. C. (2017). Isolation and Gender Conflicts in Nathaniel Hawthorne's The Scarlet Letter: Aspects of Gender Conflict in English Literature, Language in India, 17 (4). Retrieved from www.languageinindia.com

23. Wang, Y. (2017). Misogyny or Feminism? A Probe into Hawthorne and His The Scarlet Letter. English Language and Literature Studies, 7 (2), 139-143. https://doi.org/10.5539/ells.v7n2p139

24. Wolman, B. B. (1968). Oedipal complex and personality development', 'The Unconscious Mind: The Meaningof Freudian Psychology. New Jersey: A Spectrum Book.

25. World Health Organization (2015). Sex and gender. Archived from the 'original' on 2015-08-18. 